\title{
Puerto Rican Women's Struggle for Suffrage
}

\author{
LA LUCHA DE LAS MUJERES PUERTORRIQUEÑAS POR EL SUFRAGIO
}

\author{
Margaret Power \\ Illinois Institute of Technology, Illinois \\ https://orcid.org/0000-0003-4114-8645 \\ power@iit.edu
}

When Puerto Rican women struggled for the right to vote they confronted class, gender, and race-based challenges, as did most, if not all, women who sought enfranchisement. However, Puerto Rican women also faced one additional complication. Puerto Rican was (and is) a U.S. colony, and Washington exerted an undue influence on Puerto Rican women's battle for suffrage.

After the United States invaded and colonized Puerto Rico in 1898, all significant political decisions regarding the Caribbean archipelago were made in Washington. In 1904, the U.S. Congress granted Puerto Rican men the right to vote in insular elections, but not federal elections ${ }^{1}$. It made all Puerto Ricans U.S. citizens in the 1917 Jones Act. The Nineteenth Amendment, which enacted voting rights for U.S. women, did not include Puerto Rican women ${ }^{2}$. It took the combined efforts of

1 Puerto Rican men first obtained voting rights in 1897, when the archipelago was a Spanish colony. In 1899 the U.S. colonial government restricted voting to literate or tax-paying men (Suárez Findlay 117). Puerto Ricans who live in Puerto Rico are still not able to vote in federal elections.

2 According to colonial officials, Puerto Rico was an "unincorporated territory" and was not included (Ayala and Bernabe 69). 
Puerto Rican suffragists and their political allies, and several decades of struggle, until all Puerto Rican women were able to cast their ballots along with Puerto Rican men.

U.S. colonial rule engendered significant changes in the Puerto Rican economy, which, in turn, directly effected women. The expansion of U.S. and Puerto Rican sugar interests resulted in their takeover of land previously worked by smaller, family-based farms, forcing Puerto Ricans to labor as low-paid workers on the sugar estates or migrate elsewhere in search of employment. As capitalist relations increasingly penetrated Puerto Rico and Puerto Ricans needed money to survive in the burgeoning market economy, more and more women joined the paid work force, primarily in the needlework and tobacco industries. Women's proletarianization brought them into contact with other women in similar circumstances and converted them into important breadwinners for their families (Colon, Mergal, and Torres 16).

Working in tobacco production exposed these women to new ideas because they hired readers to read out loud to them to break the monotony of rolling cigars and to educate and politicize them (Tinajero 123-24). These women's new positionality vis- $\dot{a}$-vis their families, each other, and politics stimulated their demands for greater rights, including suffrage.

The changes U.S. colonialism brought about did not only impact poorer women. Other women, too, responded by asserting their claims on the political system. Historian Isabelle Picó argues that upper and middle-class women's participation in the suffrage movement stemmed from economic dislocations their families suffered due to U.S. colonialism that resulted in small and middle-sized landowners losing their land and moving to cities. There, the landowners' daughter(s) received more education, "respectable jobs" opened up, and women entered the professions, which heightened their independence and increased their desire and capacity to be politically and electorally active (Picó 54).

The Puerto Rican women's suffrage movement gained steam in the 1910 s, but its roots lie in the 1800s. Revolutionaries like pro-independence supporter Ramón Emeterio Betances and upper-class feminists like Ana Roqué de Duprey linked the emancipation of women to education and the general acquisition of women's rights ${ }^{3}$. Roqué de

3 Indeed, as Colón, Mergal, and Torres point out: "Most of the most recognized suffragist leaders and for women's rights were teachers" (19). 
Duprey launched the first Puerto Rican feminist publication $\mathrm{La} \mathrm{Mu-}$ jer in 1894 (Azize Vargas 27). In 1917 she published El Heraldo de la Mujer, which defined itself as "the monthly magazine that defends the rights of women" (El Heraldo 1) ${ }^{4}$. The magazine, which was published in both Spanish and English, included news of women's suffrage and emancipatory organizations and activities from around the world, with a particular focus on Latin America. It reported on the work of feminists like Paulina Luisi of Uruguay and Hermilia Galindo of Mexico and the death of the president of the National Council of Women of Argentina. The publication defined itself as the organ of the Alianza Femenina Latino Americana (El Heraldo 15).

Diverse forces, including the Federación Libre de Trabajadores (FLT), the Socialist Party, a smattering of politicians, and a number of women's suffrage groups agitated for Puerto Rican women's voting rights beginning in the early 1900s. Three women first called for women's voting rights at the FLT's 1908 Congress. The Assembly resolved to back the resolution, which read, "the Legislative Committee of the Federation will introduce a law in the Puerto Rican Legislative Houses that will grant women the right to vote" (Azize Vargas 65; Federación Libre de los Trabajadores 151). The Socialist Party took up the demand after it began in 1915 (Colon, Mergal, and Torres 42; Suárez Findlay 156). Nemesio Canales, a member of the Puerto Rican legislator and the Union Party, presented a bill "For Women's Legal Emancipation," which included the right to vote, in 1909 (Canales 176) 5

The Nineteenth Amendment's exclusion of Puerto Rican women spurred supporters of women's voting rights to form various suffrage organizations. Conflicting class interests distinguished the groups from each other. The key issue that divided them was whether or not they backed all women gaining voting rights or just those who were literate, that is those who had the resources and time for education ${ }^{6}$. The Socialist Party advocated universal suffrage rights for all women, both because it recognized women's right to vote and because it knew

4 By 1918, El Heraldo de la Mujer was a bi-monthly publication.

5 Canales writes that the male representatives "viewed my proposal with an outburst of scornful laughter" (176).

6 For discussion of these groups see: (Colón, Mergal, and Torres 42-43). 
that the majority of poor and working class women, many of whom were illiterate and of Afro-descent, would back its candidates. Some of the upper-class women suffragists advocated limited voting rights for women because they sought to defend the class-based nature of the electorate and their own interests (Picó 54).

Aside from the Socialist Party, none of the other Puerto Rican parties backed voting rights for women (Azize Vargas 102). Led largely by upper-class men of European descent, both the Republican and Union parties, two of Puerto Rico's principal political parties, sought to defend their gender and class privileges and position. To this end, they upheld and propagated a gendered discourse that essentialized women and men and assigned them to two separate and distinct, supposedly complementary, definitely unequal, spheres. Men dismissed the idea of women voting with stereotyped notions such as the act of voting was too strenuous and degrading for women's fragile and pure constitution, women's duties were limited to the household, and political differences could create conflicts between husband and wife (Colón, Mergal, and Torres 41).

The pro-independence Nationalist Party of Puerto Rico's position on women's suffrage mirrored its overall perspective on politics and elections, as articulated by Pedro Albizu Campos, party president. Albizu thought voting rights reflected power relations in any given nation. Thus, in a white supremacist nation like the United States, "More than sixteen million North Americans still can't vote in their country because they have African blood in their veins." He added, however, "one virtue of suffrage . . is it [gives voters] the power to . . modify the constitution." But, he pointed out, this benefit did not apply to Puerto Rico because the "imperial occupying force --the United States--sets up the rules" governing the archipelago. For that reason, Puerto Rico could not hope to achieve liberation by voting to end U.S. colonialism because "neither citizenship nor [real] suffrage exists" in the archipelago (Albizu Campos, "Sufragio" 2-3).

Albizu wrote two essays on women and elections that were published in El Mundo, the principal newspaper in Puerto Rico. For Albizu, the justification for women's suffrage revolved around women's position on independence, not on their intrinsic right to elect those who governed them. His second essay asked, "Why do women want [voting rights]? 
To reinforce colonialism? To annex Puerto Rico to the United States? Or to use them in favor of independence for la patria (the motherland)?" (Albizu Campos, "La mujer libertadora" s/p). Isabel Abreu de Aguilar, President of the Island Association of Women Voters, one of the suffragist organizations, responded to his queries from the first essay $^{7}$. Albizu cited her in his second essay. "The ideal proclaimed by the Nationalist Party is so beautiful [...] that no well-founded argument, one based on high ethical principles, can oppose it. We will awaken women's awareness of their strength and their responsibility and exhort them to use them honorably for the good of Puerto Rico" (ibid.). To which Albizu responded, "We salute la mujer libertadora (the liberating woman). La patria wants her to immediately add her strength [to the struggle for independence]" (ibid.). However, because Albizu believed that women and men's "most important civic duty [...] was to immediately constitute the free, sovereign, and independent republic," the right to vote in the U.S. colony was of little consequence to him (Albizu Campos, "Feminismo" 1) . $^{8}$

Puerto Rican representatives' obdurate refusal to consider granting voting rights for women stymied Puerto Rican suffragists' attempts to pass pro-voting legislation. So, leaders from the Liga Social Sufragista, one of the elite women's suffrage associations, took the unusual step of taking their case to the U.S. Senate in $1928^{9}$. The women sought to amend the 1917 Jones Act, which had granted citizenship to Puerto Ricans, to read "That the right to vote shall not be denied or abridged on account of sex" (U.S. Senate 1). Dr. Marta Robert, secretary of the

7 Abreu de Aguilar and Ana Roque de Duprey, who spoke out for women's rights in the late 1800 s, fought for the extension of the vote to all women, including illiterate ones (Colón, Mergal, and Torres 43).

8 It is important to note that two years later, after the 1932 election, the Nationalist Party adopted the position of retraimiento and refused to participate in any elections as long as Puerto Rico remained a colony of the United States.

9 For an excellent discussion of elite women's conflict with elite men on the issue of voting rights and the women's recourse to the U.S. Congress to pressure the male colonial elite to grant them suffrage, see Gladys M. Jiménez-Muñoz, "So We Decided to Come and Ask You Ourselves': The 1928 U.S. Congressional Hearings on Women's Suffrage in Puerto Rico". Puerto Rico Jam: Essays on Culture and Politics. Frances Negrón-Muntaner and Ramón Grosfoguel, Minneapolis, University of Minnesota Press, 1997, pp. 140-168. 
Liga and director of a maternity hospital in San Juan, presented the case for Puerto Rican women's enfranchisement. In a pointed refutation of men's opposition to women voting, she argued that "more than 30 countries... have admitted woman suffrage," She added, Puerto Rican women are "prepared" to vote since they are "educated" and "cultured," and women's "maternal duties and domestic duties" would not "suffer" since a lot of "women in Porto Rico (sic) [...] have been working for a long time" (U.S. Senate 3). She drew on a gendered argument to explain why, in fact, women should vote. "[W]e have a higher understanding of the necessities of life. We bring up children. We educate them. We know what they need. If we know what our children need, if we know what our homes need, I think that we can find out better than men what our country needs" (U.S. Senate 3-4).

Rosa Emanuelli, a school teacher and member of the Liga Social Sufragista also addressed the hearing. She, too, drew on women's role as mothers to push for voting rights, which she tied to U.S. citizenship. "We [women] believe that as long as we have been entrusted with the education of children to be good American citizens, we ought to have the right to vote" (U.S. Senate 5). Referring to the Nineteenth Amendment, she continued, "we believe that as American citizens we are in the same position as women in the United States" (U.S. Senate 5-6).

Félix Cordova Dávila represented the official voice of the Puerto Rican government. A member of the Union Party, he was Puerto Rico's four-term Resident Commissioner in the U.S. Congress ${ }^{10}$. He testified he was "strongly in favor of woman suffrage" (U.S. Senate 20). However, he opposed the U.S. Congress determining whether or not Puerto Rican women should vote (although it had previously ruled that Puerto Rican men could vote), because "the Porto Rican legislature should be left to decide questions of a local nature and not the American Congress." He added that he believed that "a literacy test is a good thing," thus indicating he sought to limit voting privileges to educated, elite women and exclude poor, working-class women (U.S. Senate 21).

The women's plea to the U.S. Congress had its desired impact on the Puerto Rican legislature. Largely in order to prevent Washington from

10 Puerto Rican Resident Commissioners represent Puerto Rico in the U.S. House of representatives. However, they, like Puerto Ricans in Puerto Rico, have no voting rights. 
passing legislation granting Puerto Rican women the right to vote, it sanctioned voting rights for literate women in 1929 (Ayala and Bernabe 60). After the Socialist Party formed a coalition with the Republican Party, elected officials extended voting rights to include all women in 1935 (Colón, Mergal, and Torres 44).

BibliografíA

Albizu Campos, Pedro. "Feminismo y la Independencia Patria". El Mundo, May 20th, 1930, pp. 1-4. . "La mujer libertadora”. El Mundo, May 24th, 1930, s/p. "Sufragio". Revolución 1, No. 7, August 24, 1931, 2-3.

Ayala, César and Rafael Bernabe. Puerto Rico in the American Century. A History Since

1898. Chapel Hill, University of North Carolina Press, 2017.

Azize Vargas, Yamila. La Mujer en la Lucha. Río Piedras, Editorial Cultural, 1985.

Canales, Nemesio R. Paliques. Río Piedras, Universidad de Puerto Rico, 1952.

Colon, Alicia, Margarita Mergal, and Nilsa Torres. Participación de la mujer en la historia de Puerto Rico. Río Piedras, Centro de Investigaciones Sociales, 1986.

El Heraldo de la Mujer no. 22, June 30, 1919.

Federación Libre de los Trabajadores. Procedimientos del Sexto Congreso de la F.L.T. de Puerto Rico. San Juan, PR, 1910.

Picó, Isabel. "The History of Women's Struggle for Equality in Puerto Rico," in The Puerto Rican Woman. Perspectives on Culture, History, and Society. (New York: Praeger, 1986), 54.

Suárez Findlay, Eileen J. Imposing Decency: The Politics of Sexuality and Race in Puerto Rico, 170-1920. Durham and London, Duke University Press, 1999. 
Tinajero, Araceli. El Lector. A History of the Cigar Factory Reader. Translated by Judith E. Grasberg. Austin, University of Texas Press, 2010. U.S. Senate. "Woman Suffrage in Porto Rico (sic)". April 25, 1928. 